\title{
FLOT1 wt Allele
}

National Cancer Institute

\section{Source}

National Cancer Institute. FLOT1 wt Allele. NCI Thesaurus. Code C122748.

Human FLOT 1 wild-type allele is located in the vicinity of $6 \mathrm{p} 21.3$ and is approximately 15 $\mathrm{kb}$ in length. This allele, which encodes flotillin-1 protein, may play a role in caveolae structure. 